2020-06-22

\title{
Improved bathymetry leads to 4000 new seamount predictions in the global ocean
}

\section{yesson, $\mathrm{C}$}

http://hdl.handle.net/10026.1/16156

\subsection{4/111.444/000044.v1}

UCL Open: Environment Preprint

All content in PEARL is protected by copyright law. Author manuscripts are made available in accordance with publisher policies. Please cite only the published version using the details provided on the item record or document. In the absence of an open licence (e.g. Creative Commons), permissions for further reuse of content should be sought from the publisher or author. 


\section{^UCLPRESS}

Article title: Improved bathymetry leads to 4000 new seamount predictions in the global ocean

Authors: Chris Yesson[1], Tom Letessier[2], Alex Nimmo-Smith[3], Phil Hosegood[4], Andrew Brierley[5], Marie Harouin[6], Roland Proud[7]

Affiliations: Zoological Society of London \& University College London[1], Zoological Society of London[2], University of Plymouth[3], University of St Andrews[4]

Orcid ids: 0000-0002-6731-4229[1], 0000-0003-4011-0207[2], 0000-0003-3108-9231[3], 0000-0002-4415-7152[4], 0000-0002-6438-6892[5], 0000-0002-8647-5562[7]

Contact e-mail: ucbtcye@ucl.ac.uk

License information: This is an open access article distributed under the terms of the Creative Commons Attribution License (CC BY) 4.0 https://creativecommons.org/licenses/by/4.0/, which permits unrestricted use, distribution and reproduction in any medium, provided the original author and source are credited.

Preprint statement: This article is a preprint and has not been peer-reviewed, under consideration and submitted to UCL Open: Environment Preprint for open peer review.

DOI: $10.14324 / 111.444 / 000044 . v 1$

Preprint first posted online: 22 June 2020

Keywords: Seamounts, Bathymetry, Knolls, Environmental science 
Dear editor,

This is a follow up manuscript to the highly cited "The global distribution of seamounts based on 30 arc seconds bathymetry data" (https://doi.org/10.1016/j.dsr.2011.02.004 - currently 125 citations). This manuscript provides an update of the seamount predictions, along with a valuable observation on the reliability of bathymetry grids.

Kind regards

Chris Yesson \& co-authors 


\section{Improved bathymetry leads to 4000 new seamount predictions in the 2 global ocean}

3 Chris Yesson ${ }^{1}$, Tom B Letessier ${ }^{1}$, Alex Nimmo-Smith ${ }^{3}$, Phil Hosegood ${ }^{3}$, Andrew S. Brierley ${ }^{2}$, Marie 4 Hardouin $^{1,4}$, \& Roland Proud ${ }^{2}$

$5 \quad{ }^{1}$ Institute of Zoology, Zoological Society of London, Regent's Park, London, NW1 4RY, UK

$6{ }^{2}$ Pelagic Ecology Research Group, Scottish Oceans Institute, School of Biology, University of St Andrews, St Andrews, 7 Fife, KY16 9TS, UK

$8 \quad{ }^{3}$ School of Biological \& Marine Science, University of Plymouth, Plymouth, Devon, PL4 8AA, UK

$9 \quad{ }^{4}$ Imperial College London, Silwood Park, Ascot, Berkshire, SL5 7PY

10 Correspondence to: Chris Yesson (chris.yesson@ioz.ac.uk)

11 Abstract. Seamounts are important marine habitats that are hotpots of species diversity. Relatively shallow peaks, increased productivity and offshore locations make seamounts vulnerable to human impact and difficult to protect. Present estimates of 13 seamount numbers vary from barely 10000 to more than 60000), because locating and identifying them remotely can be 14 difficult. Seamount locations can be estimated by extracting conical shaped features from bathymetry grids. These predicted 15 seamounts are a useful reference for marine researchers and can help direct exploratory surveys. However, these predictions are dependent on the quality of the surveys underpinning the bathymetry. Historically, quality has been patchy, but is improving as mapping efforts step up towards the target of complete seabed coverage by 2030.

18 This study presents an update of seamount predictions based on the most recent SRTM30 global bathymetry. This update 19 was prompted by a seamount survey in the British Indian Ocean Territory, where locations of two putative seamounts, based 20 on several previous global seamount predictions, were visited, but no such features were detected during echosounder 21 surveys. An examination of Admiralty charts for the area showed that the summits of these putative features had soundings reporting "no bottom detected at this depth" where "this depth" was similar to the seabed reported from the bathymetry grids: we suspect that these features likely resulted from an initial misreading of the charts. We show that perhaps 15 phantom seamount features, derived from a misinterpretation of no-bottom sounding data, persist in current global bathymetry grids and updated seamount predictions. Overall, we predict 37,889 seamounts, an increase of 4,437 from the previous prediction derived from an older global bathymetry grid. This increase is due to greater detail in newer bathymetry grids as acoustic mapping of the seabed expands.

\section{Keywords}

29 Seamounts; Knolls; Bathymetry 
31 Seamounts are 'undersea mountains', and although many definitions of this term have been used, they are commonly described as conical features that rise more than $1000 \mathrm{~m}$ above the surrounding seabed (IHO 2008). Seamounts are important marine habitats, they provide a pathway for localized production (Hosegood et al., 2019), often increasing surrounding biomass and species diversity (Letessier et al., 2017), they can be hotspots of predator biodiversity in the open ocean (Morato et al., 2010), home to habitat-engineering species such as cold water corals (Tracey et al., 2011), important spawning grounds (Tsukamoto, 2006), and even act as refugia from ocean acidification for carbon-calcifying species

\section{7 (Tittensor et al., 2010).}

38 The increased productivity associated with seamounts makes them attractive targets for fishing, and hence vulnerable to human impacts, particularly those with accessible summits near the surface. Fishing gear can cause long-lasting damage to habitat forming organisms associated with some seamounts (Althaus et al., 2009). Protection of seamount habitats is a priority for marine conservation (Morato et al., 2010), but our knowledge on these habitats remains limited, with estimates of only $0.4-4 \%$ of seamounts having been directly surveyed (Kvile et al., 2014).

Direct surveys require significant investment of resources and planning, and fundamental to this is identification of locations of interest for the survey. However, we do not yet know how many seamounts there are, with estimates ranging from the tens to hundreds of thousands (Yesson et al., 2011). This has led to the publication of many predictive maps and databases of potential seamount locations, commonly based on pattern recognition of underlying bathymetry data (Yesson et al., 2011; Harris et al., 2014), but also using satellite altimetry to detect larger features (Wessel, Sandwell, and Kim 2010; Kim and 48 Wessel, 2011).

49 Seamount predictive maps are dependent on the underlying data to extract features. Global bathymetry grids such as GEBCO (Weatherall et al., 2015) and SRTM (Becker et al., 2009) are themselves models based on a combination of soundings (i.e. high resolution acoustic surveys) and satellite altimetry (lower resolution data from satellite sensors). Satellite- altimetry provides global coverage and is the foundation of bathymetry models, but these sensors cannot determine small features (i.e. seamounts under $1.5 \mathrm{~km}$, Wessel et al., 2010). Acoustic surveys generate data best suited for determining seabed depth and these are used to constrain models used to create bathymetry grids (Becker et al., 2009). Despite global efforts to improve coverage, such as the Nippon Foundation-GEBCO challenge to survey the ocean floor across the globe by 2030 (Wölfl et al., 2019), soundings in the latest bathymetry grids are limited to a small proportion of the ocean, and the majority of bathymetry grid data is derived from the underlying model rather than acoustically surveyed. For example, only $18 \%$ of current GEBCO grid cells (each $30 \times 30$ arc seconds $\approx 1 \times 1 \mathrm{~km}$ at the equator) are directly supported by acoustic surveys (Weatherall et al., 2015). With so little sounding data available, there is a premium on making full use of all data available, and historical soundings (based on weighted lines) have been extracted from nautical charts to expand these data (Becker et al., 2009). 


\section{BIOT Seamount Survey}

62 The British Indian Ocean Territory (BIOT) is a region of the Indian Ocean encompassing a variety of undersea features,

63 including the flat shallow banks of the Chagos Archipelago, and the high slopes of the Chagos-Laccadives ridge, and depths

64 beyond 5000m (Sheppard et al., 2012). The area could be home to as many as 86 seamounts, based on estimates from an 65 automated seamount-recognition algorithm applied to version 6 of the SRTM global bathymetry grid (Yesson et al., 2011).

66 Two of these predicted seamounts, clearly discernible on the latest bathymetry grids, were targeted during a 2016 survey 67 around the Chagos Archipelago (Letessier et al., 2016), between 5-24th February. These are seamounts ID 4050548 (latitude $68-5.354$, longitude 71.292, summit depth 481m) and ID 4060551 (lat. -5.733, long. 71.396, depth 141m) from Yesson et al., 69 (2011). The survey sought to visit these features for the purpose of establishing baseline monitoring sites for mobile oceanic 70 predators (Letessier, Bouchet, and Meeuwig 2017). Seamounts in BIOT have previously been shown to be important 71 location of bio-physical coupling between reef and pelagic ecosystems, and may therefore support elevated numbers of 72 predators (Hosegood et al., 2019; Letessier et al., 2016; Letessier et al., 2019). Acoustic data were collected using a Simrad 73 (Bergen, Norway) EK60 echosounder operating at $38 \mathrm{kHz}$ with a pulse length of $1.024 \mathrm{~ms}$ and ping rate of $2 \mathrm{~s}$. At these 74 settings, the seabed was detectable up to $1,500 \mathrm{~m}$ below the surface. Seabed was detected at around this depth for seamount A 75 (predicted depth 183m), but no seabed was detected around the area of seamount B (predicted depth 491m) despite circling 76 around the supposed summits up to $5 \mathrm{~km}$ (Fig. $1 \& 2$ ). 


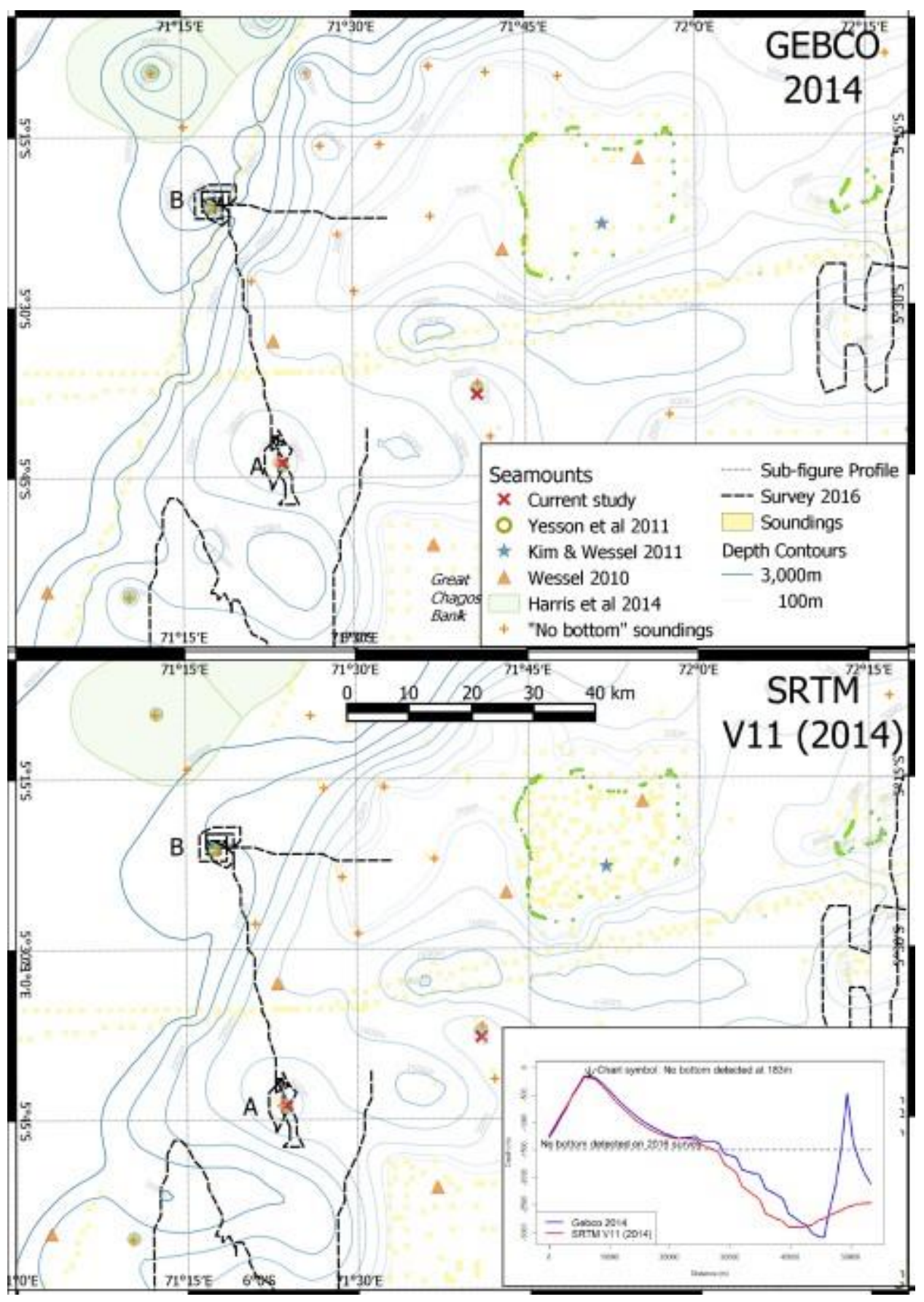

79 Figure 1: Location of survey conducted in 2016. Top shows depth contours based on the 2014 GEBCO bathymetry grid, bottom 80 shows depth contours derived from SRTM v11. Both grids indicate the presence of a conical seamount c.20km NW of the Great 81 Chagos Bank. No feature was detected by the 2016 survey (ship's track shown with black dashed line). Around 40km north of this, 82 is another predicted seamount, again not detected on the 2016 survey. This feature is predicted by the GEBCO grid, but is not shown in the SRTM grid (although present in previous versions). Map projection UTM zone 43 south (epsg:32743). 
(a) Seamount A

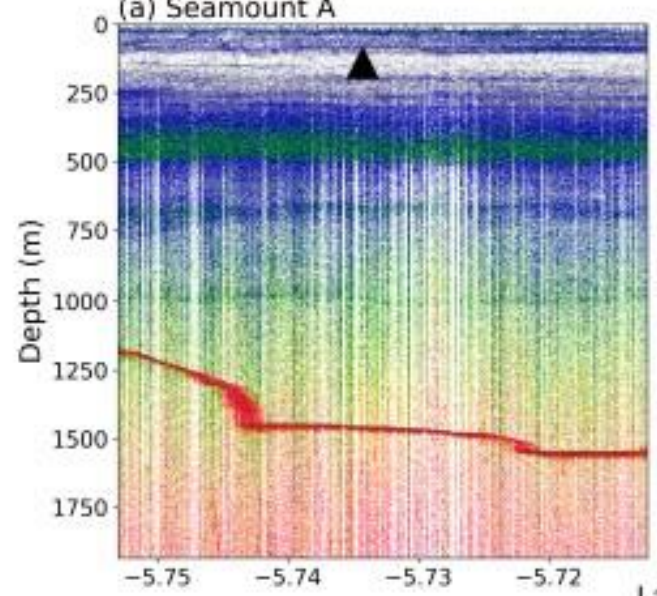

(b) Seamount B

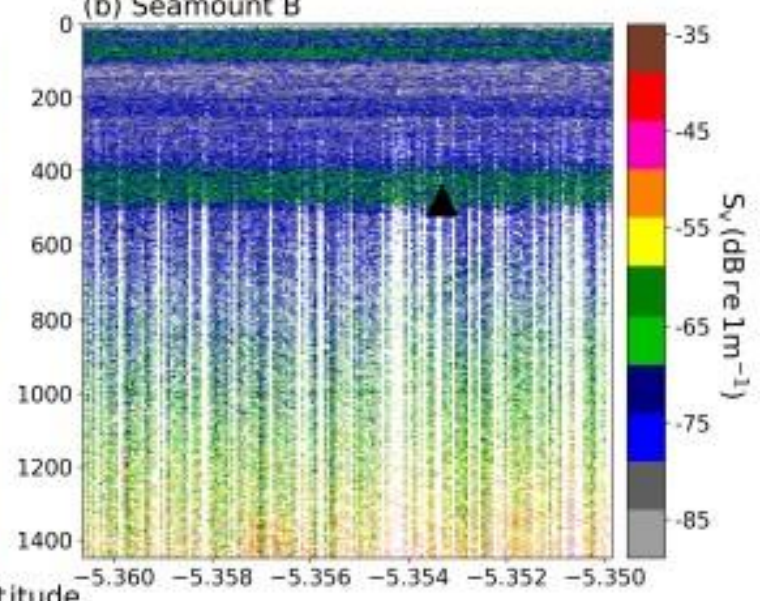

Figure 2: Latitudinal transects across apparent positions of the two phantom seamounts. Black triangles indicate the position and summit depth of the predicted seamounts. Colormap is Volume Backscattering Strength (Sv). A deep scattering layer was observed at c.450m for both sites. Seabed was observed at site A c.1500m. No seabed was detected for site B.

An examination of the admiralty chart for the region provided some insight. Soundings on charts are recorded by displaying the depth reading over the location. A different class of sounding is also recorded. Soundings where no bottom was recorded are annotated with $\frac{\cdot}{\text { Depth }}$ at the location of the sounding. These soundings are typically old, prior to the nineteenth century, dating from when soundings where conducted using handheld, weighted, lead lines, before the widespread use of sounding machines. It is easy to mistake these as bottom soundings, and this appears to be the root cause of the 'phantom seamounts'. For seamount A (Fig. 1) there is a sounding in the chart at the summit of the mound seen on the bathymetry grids. The chart shows no bottom recorded at $183 \mathrm{~m}$, while the GEBCO depth at this cell is $179 \mathrm{~m}$ and SRTM depth is $183 \mathrm{~m}$.

However, the SRTM grid at the site of seamount B does not show a seamount-like feature, in contrast to GEBCO, which shows an isolated point of markedly higher elevation, which is interpreted as a conical seamount-like peak by seamount detection algorithms. It is noted that previous versions of the SRTM grid showed a seamount-like feature at this location. The version history reports the removal of isolated and outlier "bad pings" prior to the construction of version 11 . The revision of SRTM has removed other seamount-like features from the revised bathymetry grid (i.e. NW corner of Fig. 1). It is apparent that bathymetry grids such as GEBCO and SRTM have mistakenly used these "no seabed detected" observations as soundings indicating seabed depth, and in regions with sparse sounding data, these spatially isolated erroneously interpreted records are sufficient to create a local maxima that creates the appearance of a seamount in the final bathymetry grid.

This study aims to update the Yesson et al., (2011) seamount predictions using the latest available bathymetry, and assess the impact of no bottom sounding data on the prediction of seamounts. 
108 Version 11 of the Shuttle Radar Topography Mission global bathymetry (Becker et al., 2009 - version 11 released 2014) was

109 used to update the seamount prediction estimates of Yesson et al., (2011), using the same methodology previously reported

110 based on the local radial inspection of the surrounding area of local summits (Yesson et al., 2011).

111 New seamount predictions were compared with the previous dataset (Yesson et al., 2011 - henceforward the 'old' dataset).

112 Seamounts were defined as in the old dataset if the seamount bases of the latest predictions encompassed the summit of old

113 seamount predictions. Seamount bases are defined by 8 radii $45^{\circ}$ apart that terminate at the point the descent from the

114 seamount summit levels off up to a maximum of $20 \mathrm{~km}$ from the summit (thus the maximum base area is $\sim 1,131 \mathrm{~km} 2$ ). The

115 seamount bases can (and do) encompass multiple peaks in the old dataset.

116 A dataset of 'no bottom sounding' observations was provided by Oceanwise Ltd, from a dataset of depth readings from 117 digitised admiralty charts. These data include 1009 observations from charts covering the majority of the Atlantic and East 118 Pacific, but with little data from the Southwest Indian Ocean and West Pacific. The depth readings of no-bottom soundings 119 that were spatially located within seamount bases were compared with the summit depths.

\section{Results}

121 The total number of seamounts predicted based on the SRTM v11 bathymetry is 37,889. A map of these is presented in Fig. 122 3. There are 32,340 seamounts in the new dataset that overlap with predictions from Yesson et al., (2011) and 5,549 (15\%) 123 that do not. Conversely, of the Yesson et al., (2011) seamount predictions there are 3,429 / 33,452 (10\%) that do not overlap 124 with the seamount bases of the new dataset.

125 Of the 1009 'no bottom sounding' records, only 15 overlap with seamounts that are similar in depth (+/-50m) to the peak of 126 the predicted seamount. In contrast there are 14 seamounts that fit this pattern from the 2011 dataset. These "phantom 127 seamounts" are focused in the Indian Ocean (12/14 from 2011 data and 12/15 from the updated dataset), with 4 potential 128 phantom seamounts around Chagos Bank and 6 from the southern Mascarene Plateau (Fig. 4). 


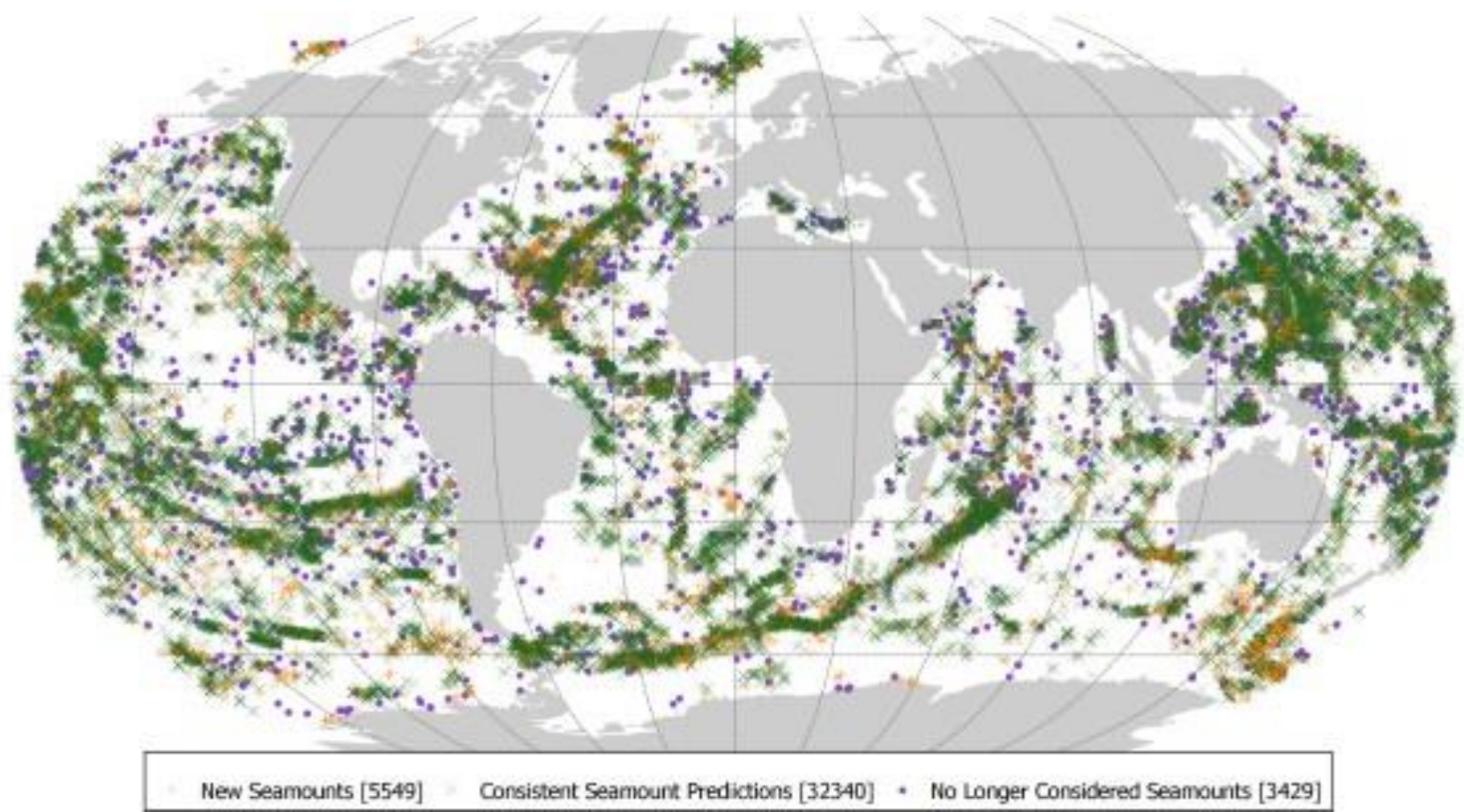

131 Figure 3: Map of predicted seamounts. New Seamounts are those in the new prediction that are not found in the Yesson et al., (2011) dataset. "Consistent predictions" are new predictions that are spatially consistent with Yesson et al., (2011), while those no 133 longer considered seamounts are present in Yesson et al., (2011) but not in the updated dataset. Robinson map projection 134 (EPSG:54030). Grid lines at $\mathbf{3 0}^{\circ}$ intervals. 


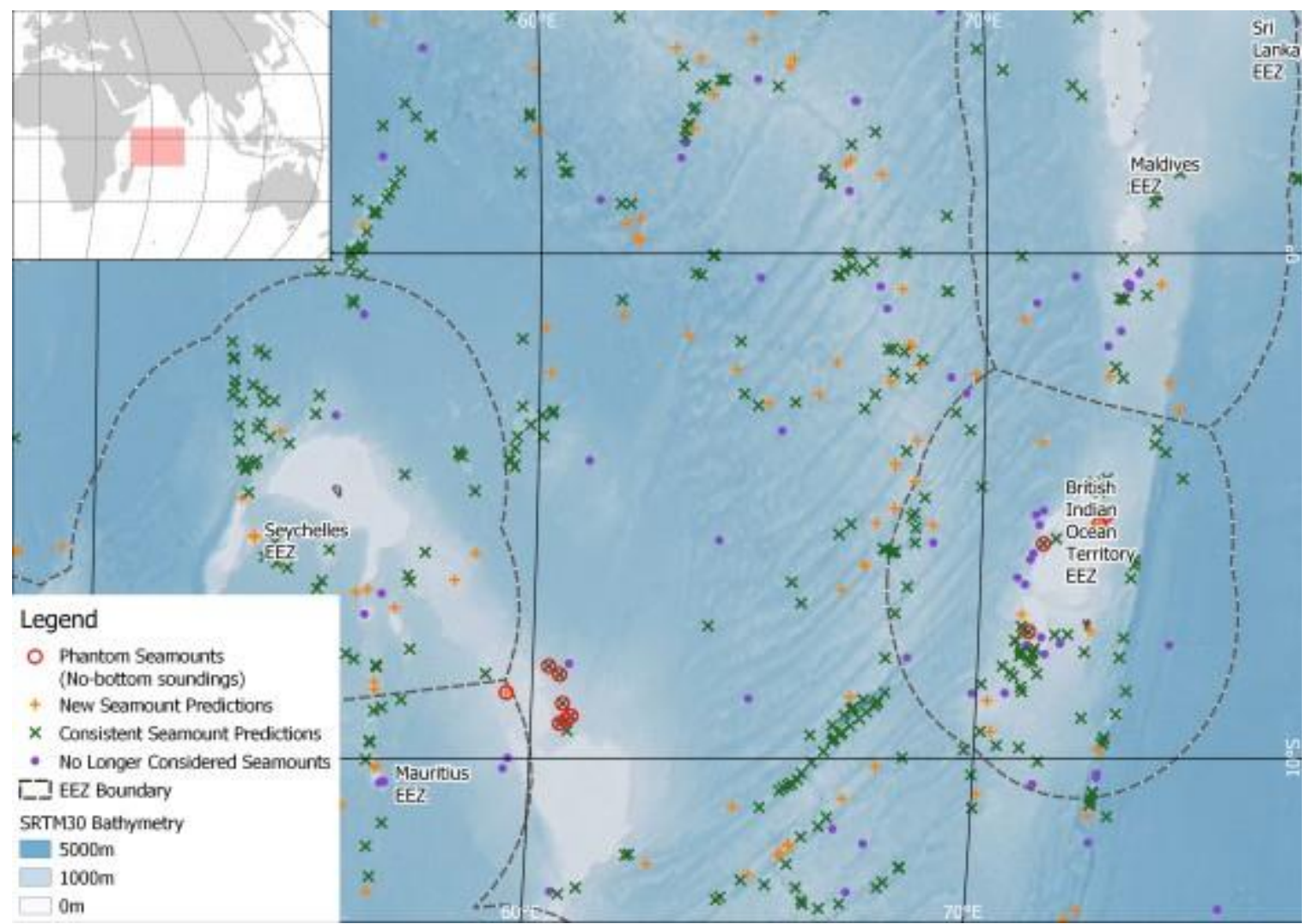

136 Figure 4: Focus on Seamounts of NW Indian Ocean. Robinson map projection (EPSG:54030).

\section{Discussion}

138 The 37,889 seamounts predicted from the latest SRTM bathymetry represents an increase in number $(4,437=13 \%)$ of

139 seamounts predicted from the previous study $(\mathrm{N}=33,452)$. The revised predictions are higher than other predictions that post-

140 date Yesson et al., (2011) such as 24,643 seamounts in the Kim \& Wessel (2011) dataset and 10,234 of Harris et al (2014),

141 but it is still lower than some other predictions, e.g. 68,669 of Costello et al., (2010). It is worth noting that each of these

142 studies uses different ways of detecting seamounts, for example Harris et al., (2014) have a stricter definition of seamount

143 that excludes features along ridges.

144 Regardless of the methodology used, it is important to keep prediction datasets up-to-date with the latest bathymetry grids.

145 We expect the expansion of multibeam echosounder data (Wölfl et al., 2019) to allow the detection of smaller $(<1.5 \mathrm{~km})$ 
146 features in regions where previously bathymetry grids relied on only coarse resolution satellite-derived data, which is why

147 authors have extrapolated their 'detected' seamount numbers to higher global estimates (e.g. Kim \& Wessel, 2011 detect

14824,643 seamounts, but extrapolate this to a global total of 40,000-55,000). This pattern of increased seamount detection as

149 more acoustic data becomes available fits our observation.

150 However, there is a competing pressure that may lead to a reduction of seamount numbers, as isolated 'bad pings' or

151 erroneous readings are removed from bathymetry grid construction, so features defined by these mistakes will be removed

152 (Becker et al., 2009; Weatherall et al., 2015). Although the scale of this error appears to be small, and the bathymetry grids

153 are improving their products, all of these issues have not yet been removed.

154 Finally, although these predictions are based on a global bathymetry grid, we note that seamount predictions based on the

155 lat-long bathymetry grid perform poorly at high latitudes where there is a large spatial distortion. Seamount predictions for

156 Arctic and Antarctic regions should be remade based on polar specific grids such as the International Bathymetric Chart of

157 the Arctic Ocean (IBCAO - Jakobsson et al., 2012).

\section{Conclusion}

159 Bathymetry grids are continually improving (Wölfl et al., 2019), whether that be from new multibeam acquisition, such as 160 that collected during the search for Malaysian Airlines flight MH370 (Smith and Marks 2014), or improved satellite gravity 161 data (Sandwell et al., 2014). However, these bathymetry grids still rely on sparse sounding data for many regions, and thus

162 have the capacity to mislead if in-valid historical weighted line measurements are used in the construction of bathymetric 163 models as isolated falsely interpreted records can lead to the appearance of "phantom seamounts". Therefore, it is important 164 that we use all the information available, including multiple seamount predictions, multiple bathymetry models and printed 165 charts to assess potential seamount distributions, particularly when planning surveys to unsampled seamounts, or in the arena 166 of conservation planning, where seamount distributions can be used as proxies for endangered predator distributions 167 (Bouchet et al., 2014).

\section{Data availability}

169 Updated seamount predictions are available to download at (tbc). 
171 CY \& TL conceived the work. TL, ANS, PH, AB \& RP planned and conducted fieldwork. CY, TL \& MH assembled the 172 data. CY performed analysis. All contributed to writing.

\section{Competing interests}

174 The authors declare that they have no conflict of interest.

\section{Acknowledgements}

176 We are grateful to the Bertarelli Foundation for supporting this research. Field activities were conducted under permit and with support from the Foreign and Commonwealth Office and the BIOT administration. We thank the Pacific Marlin, its Master, Chief, and crew for excellent assistance. We are grateful to Oceanwise Ltd for sharing the dataset of 'no bottom sounding' observations from the digitised admiralty charts. We thank Andrew Roy for helpful suggestions during this MSc thesis project.

\section{References}

182 Althaus, F, Williams A, Schlacher TA, Kloser RJ, Green MA, Barker BA, Bax NJ, Brodie P, Hoenlinger-Schlacher MA 183 (2009) Impacts of Bottom Trawling on Deep-Coral Ecosystems of Seamounts Are Long-Lasting. Mar Ecol Prog Ser 397: 184 279-294. https://doi.org/10.3354/meps08248.

185 Becker JJ, Sandwell DT, Smith WHF, Braud J, Binder B, Depner J, Fabre D, et al., (2009) Global Bathymetry and Elevation 186 Data at 30 Arc Seconds Resolution: SRTM30_PLUS. Mar Geodesy 32: 355-71. 187 https://doi.org/10.1080/01490410903297766.

188 Bouchet PJ, Meeuwig JJ, Salgado Kent CP, Letessier TB Jenner CK (2014) Topographic Determinants of Mobile Vertebrate

189 Predator Hotspots: Current Knowledge and Future Directions. Biol Rev 90: 699-728. https://doi.org/10.1111/brv.12130.

190 Harris PT, Macmillan-Lawler M, Rupp J, Baker EK. (2014) Geomorphology of the Oceans. Mar Geol 352: 4-24. 191 https://doi.org/10.1016/j.margeo.2014.01.011.

192 Hosegood PJ, Nimmo-Smith WAM, Proud R, Adams K, Brierley AS (2019) Internal lee waves and baroclinic bores over a 193 tropical seamount shark "hot-spot." Prog Oceanog 172: 34-50. http://doi.org/10.1016/j.pocean.2019.01.010.

194 International Hydrographic Organization (2008) Standardization of undersea feature names: Guidelines proposal form 195 terminology, 4th edition. International Hydrographic Organization and International Oceanographic Commission, 196 International Hydrographic Bureau, Monaco, 32 pp. 
Jakobsson M, Mayer L, Coakley B, Dowdeswell JA, Forbes S, Fridman B, Hodnesdal H, Noormets R, Pedersen R, Rebesco M, Schenke HW (2012) The international bathymetric chart of the Arctic Ocean (IBCAO) version 3.0. Geophys Res Lett 28:12. https://doi.org/10.1029/2012GL052219.

Kim SS, Wessel P (2011) New Global Seamount Census from Altimetry-Derived Gravity Data. Geophys J Int 186: 615-631. https://doi.org/10.1111/j.1365-246x.2011.05076.x.

Kvile KØ, Taranto GH, Pitcher TJ, Morato T (2014) A Global Assessment of Seamount Ecosystems Knowledge Using an Ecosystem Evaluation Framework. Biol Cons 173: 108-20. https://doi.org/10.1016/j.biocon.2013.10.002.

Letessier TB, Cox MJ, Meeuwig JJ, Boersch-Supan PH, Brierley AS. (2016) Enhanced Pelagic Biomass around Coral Atolls. Mar Ecol Prog Ser 546: 271-76. https://doi.org/10.3354/meps11675.

Letessier TB, Bouchet PJ, Meeuwig JJ (2017) Sampling Mobile Oceanic Fishes and Sharks: Implications for Fisheries and Conservation Planning. Biol Rev 91: 627-646. https://doi.org/10.1111/brv.12246.

Letessier TB, De Grave S, Boersch-Supan PH, Kemp K, Brierley AS, Rogers A. (2017) Seamount influences on mid-water shrimps (Decapoda) and gnathophausiids (Lophogastridea) of the South-West Indian Ridge. Deep Sea Res Part II: Topical Stud Oceanogr 136: 85-97. https://doi.org/10.1016/j.dsr2.2015.05.009.

Letessier TB, Hosegood P, Nimmo-Smith A, Fernandes MC, Proud R, Lieber L, et al., (2016). Chagos Archipelago Consortium Pelagic Science Expedition. Scientific Report to the Bertarelli Foundation and the Foreign and Commonwealth Office. 1-55.

Letessier TB, Mouillot D, Bouchet PJ, Vigliola L, Fernandes MC, Thompson C, et al., (2019). Remote reefs and seamounts are the last refuges for marine predators across the Indo-Pacific. PLoS Biology, 17(8), e3000366. https://doi.org/10.1371/journal.pbio.3000366.

Morato T, Hoyle SD, Allain V, Nicol SJ. (2010). Seamounts Are Hotspots of Pelagic Biodiversity in the Open Ocean. Proc Nat Acad Sci 107: 9707-11. https://doi.org/10.1073/pnas.0910290107.

Morato T, Pitcher T, Clark M, Menezes G, Tempera F, Porteiro F, Giacomello E, Santos R (2010) Can We Protect Seamounts for Research? A Call for Conservation. Oceanog. 23: 190-99. https://doi.org/10.5670/oceanog.2010.71.

Sandwell DT, Muller RD, Smith WHF, Garcia E, Francis R. (2014). New Global Marine Gravity Model from CryoSat-2 and Jason-1 Reveals Buried Tectonic Structure. Science 346: 65-67. https://doi.org/10.1126/science.1258213.

Smith WHF, Marks KM. (2014) Seafloor in the Malaysia Airlines Flight MH370 Search Area. Eos Trans. AGU 95: 173-74. https://doi.org/10.1002/2014eo210001.

Tittensor DP, Baco AR, Hall-Spencer JM, Orr JC, Rogers AD (2010). Seamounts as Refugia from Ocean Acidification for Cold-Water Stony Corals. Mar Ecol 31: 212-225. https://doi.org/10.1111/j.1439-0485.2010.00393.x.

Tracey DM, Rowden AA, Mackay KA, Compton T (2011) Habitat-Forming Cold-Water Corals Show Affinity for Seamounts in the New Zealand Region. Mar Ecol Prog Ser 430: 1-22. https://doi.org/10.3354/meps09164.

Tsukamoto K (2006) Oceanic biology: spawning of eels near a seamount. Nature 439.7079: 929-929. https://doi.org/10.1038/439929a. 
231 Weatherall P, Marks KM, Jakobsson M, Schmitt T, Tani S, Arndt JE, Rovere M, Chayes D, Ferrini V, Wigley R (2015) A

232 New Digital Bathymetric Model of the Worlds Oceans. Earth Space Sci 2: 331-45. https://doi.org/10.1002/2015ea000107.

233 Wessel P, Sandwell D, Kim SS (2010) The Global Seamount Census. Oceanogr 23: $24-33$.

234 https://doi.org/10.5670/oceanog.2010.60.

235 Wölfl AC, Snaith H, Amirebrahimi S, Devey CW, Dorschel B, Ferrini V, Huvenne VA, Jakobsson M, Jencks J, Johnston G,

236 Lamarche G (2019) Seafloor Mapping-the challenge of a truly global ocean bathymetry. Front Mar Sci 6:283.

237 https://doi.org/10.3389/fmars.2019.00283.

238 Yesson C, Clark MR, Taylor ML, Rogers AD (2011) The Global Distribution of Seamounts Based on 30 Arc Seconds

239 Bathymetry Data. Deep Sea Res Part I: Oceanogr Res Papers 58: 442-53. https://doi.org/10.1016/j.dsr.2011.02.004. 